\title{
C-24 PETROLEUM EXPLORATION STRATEGIES IN MOBILE BELTS
}

FRANÇOIS ROURE', DAVID G. HOWELL ${ }^{2}$ and RUDY SWENNEN ${ }^{3}$ 'institut Français du Petrole, Rueil-Malmaison, France 2US Geological Survey 'Leuven Katholicke Universiteit

\section{INTRODUCTION}

Foreland fold-and-thrust belts (FFTB) still comprise the World's largest petroleum reserves. However, due to their structural complexity, FFTB frequently constitute a frontier for the exploration. Based on the distribution of surficial seepages, first drillings were focused on shallow targets, either in shallow anticlines near the thrust front, or in dominantly stratigraphic traps, up-slope the regional foreland flexure. Progressively, seismic surveys and other geophysical techniques improved the imagery of sub-surface geometries, leading to major discoveries in deeper structural prospects. Numerous subthrust hydrocarbon prospects have been identified since World War II in Austria in the Alps, at Lopushnia in the Carpathians, and at Tempa Rossa in the Southern Apennines. More recently, major discoveries in the Sub-Andean foothills, i.e., Cusiana and Caño Limon in Colombia, El Furrial in Venezuela and Camisea in Peru, have renewed the interest of petroleum companies for the exploration in FFTB.

Progressively, new modeling techniques and integrated approaches have provided reliable reconstructions of the evolution of petroleum systems in a number of reference FFTB, thus accounting for a better knowledge of the various parameters controlling the exploration risks in the foothills. Although progressive zonations of hydrocarbon gas and liquid occur at depth, significant commercial production presently derives from gas pools deeper than $6 \mathrm{~km}$, and future giant hydrocarbon discoveries are still expected at great depth. The maximum depth of commercial targets is essentially controlled by increasing drilling costs and decreasing reservoir's porosities, rather than by the stability of methane, known to resist to ultra-high temperatures and pressures.

It turns out that reservoir's quality becomes the dominant exploration risk in FFTB. During sedimentary and tectonic burial, both carbonate and sandstone reservoirs are rapidly modified by compaction, pressure-solution and fluid-rock interactions, and these issues require also careful multidisciplinary team work.

\section{STRUCTURAL APPROACHES}

National and international deep seismic programs have provided key informations on the crustal architecture of FTB, thus allowing the construction of realistic kinematic models accounting for the thin-skinned tectonics of the foothills, but also in areas where the basement is controlling the deformation (foreland inversions) or is even widely involved in thrust tectonics (i.e., in the hinterland of the Alps and the Pyrennes).

Seemingly, analog models (sand-box) now provide 3D, dynamic records of such tectonicaly complex structures as triangle zones, transfer zones and lateral ramps, as well as for areas where 
thin- and thick-skinned tectonics interact, making these laboratory images helpfull for the Earth scientists when interpreting fragmentary or average-quality subsurface records.

Finaly, numerical models are now used to validate the structural interpretations and to balance regional cross-sections both backward and forward, thus accounting for synorogenic sedimentation and erosion processes, as well as for regional subsidence, flexing and unflexing of the underlying lithosphere.

\section{BURIAL CURVES and THERMAL HISTORY of SOURCE ROCKS and RESERVOIRS}

Apart of the direct incidence of tectonic studies on the identification of potential prospects, the main interest of forward balanced cross-section is to provide reliable constraints on the burial history of source rocks and reservoirs $(z=f(t))$.

When coupled with simple thermal modeling, assuming dominantly conductive heat transfers across the sedimentary pile, it becomes possible to reconstruct the thermal history of any stratigraphic horizon $(\theta=\mathrm{f}(\mathrm{z}, \mathrm{t}))$, no matter it is a source rock or a reservoir. However, these models are only valid when sufficiently constrained by well data (BHT), but also by means of paleothermometers (fluid inclusions and apatites).

Finally, such thermal computation can also be used to simulate the source rock maturation and the expulsion of hydrocarbons, provided the distribution and types of kerogens are reasonably well known and the model can be calibrated by means of real maturity data (Tmax/Ro) measured on surface (outcrop) and subsurface (cores and cuttings) samples.

\section{EVOLUTION of the PETROLEUM SYSTEMS as a FONCTION of the TECTONIC AGENDA}

Coupling kinematic (tectonic) and thermal modeling is the key for a good understanding of the petroleum systems in FFTB. Effectively, it is necessary to predict, before drilling, whether the timing of structural closures is consistent with the timing of petroleum migration or not.

- The largest reserves in term of volume of hydrocarbon accumulations always occur within the foreland, up-dip the regional flexure, and account for dominantly heavy products, frequently biodegradated and difficult to extract, i.e., in the tar belts of the West Canada and Eastern Venezuela basins. These bitumen deposits result from long-range migration pathways across the foredeep basin, being moved upward by gravity and hydrodynamism.

- One can expect large oil and/or gas accumulations in the allochthonous units of the foothills only when source rock horizons have preserved some petroleum potential after their former passive margin and flexural evolution within the foreland. In such a case, tectonic burial is advocated as responsible for kerogen maturation within underthrust synclines, the resulting hydrocarbon products then migrating for a short distance toward adjacent anticlines.

\section{CRITICAL PARAMETERS CONTROLLING RESERVOIR CHARACTERISTICS in FFTB}

\section{Sandstone reservoirs}

Sandstone reservoirs occur in the former passive margin as well as synflexural and syntectonic clastics.

In many thrust belts, the magnetic fabric (AMS) and oriented thin-sections parallel to the main transport direction evidence that most anticlines still preserve the layer parallel shortening (LPS) 
signature, which was recorded by the rock matrix during early deformation, i.e., horizontal pressure-solution, when reservoirs were still' in the footwall foreland (Averbuch et al., 1992).

The main result of microthermometric studies and coeval thermal modelling is that most damaging episode related to quartz cementation occurs also in the footwall of the frontal thrust, at a time when the reservoir still belongs to the autochthon but is already submitted to horizontal compaction (LPS) within an open system for both the regional fluid flow and silica transport (Bordas, 1999).

\section{Carbonate reservoirs}

Both platform and basinal carbonates may occur in former passive margin series currently involved in foothills prospects.

Unlike for sandstone reservoirs, the depositional environment remains the most critical parameter controlling the characteristics of the rock matrix in carbonate series. However, reservoirs characteristics can be improved during the thrust belt evolution, i.e., in case of secondary dolomitization, dissolution in so-called hydrothermal karsts, and during the development of deformation features such as stylolites, joints and faults. Alternatively, late burial and tectonic accretion of carbonate units into the allochthon will provide also localy additional damaging to the rock matrix.

Foreland evolution seems to control also the distribution of most fractures and stylolitic joints in carbonates, a fraction of these inherited microstructures being eventually reactivated during subsequent episodes of folding and thrusting (i.e., during tectonic accretion and uplift). A good understanding of these successive events at both the reservoir and regional scales is crucial for the exploration in the foothills, as fluid migrations and trapping of hydrocarbons are likely to be coeval with these successive fracturing episodes.

\section{PERSPECTIVES and CONCLUSIONS}

A few parameters still need to be better constrained in order to achieve reliable predictions, i.e ., parameters dealing with the fluid flow and its incidence on fluid-rock interactions, and with the deformation of the reservoirs.

\section{Fluid-rock interactions and quantification of the water-flow}

For instance, we need now to focus on the following parameters :

- The regional fluid flow, which largely controls the efficiency of fluid-rock interactions when the reservoir is still an open system;

- The elemental composition of the circulating fluid, especially its Si content when dealing with quartz-cementation;

- The overall pressure regime and especially, the distribution of overpressured domains, which clearly account for a delay in the compaction and pressure-solution.

Until now, thermal modelling was mainly addressed assuming purely conductive heat transfers (Thrustpack simulations). However, new numerical tools (i.e., the Ceres software) allow also to simulate the compaction and fluid flow evolution in structuraly complex domains, and thus, to quantify their incidence on the overall thermal regime of the foothills.

\section{Deformation of the reservoirs}


Fault-reactivation and opening of (extrados)" fractures are likely to occur in connection with rapid changes in the curvature of the beds, i.e ., at the bend zone of the kinks. Their distribution is also likely to relate to the mode of folding.

However, the orientation of former structures, inherited from the footwall evolution, may turn to control the overall architecture of hangingwall reservoirs, as part of them are likely to be reactivated during subsequent folding and thrusting episodes.

\section{Acknowledgements}

This paper is a summary of the book «Petroleum exploration strategies in Moblile belts » by F. Roure and D.G. Howell. It ist also an outline of the major objectives addressed by the Subtrap-I Consortium (1996-1998), which was operated by IFP and sponsored by BP-Colombia, Chevron, Conoco, EAP, Enterprise, Exxon, Intevep, Lasmo, PetroFina, Premier Oil, Sipetrol, Shell, TotalCFP, with Ecopetrol, IMP-Pemex, OGDC, OGI-Albpetrol as associate members.

\section{REFERENCES}

Averbuch O., Frizon de Lamotte D. and Kissel C., 1992. Magnetic fabric as a structural indicator of the deformation path within a fold-thrust structure : a test case from the Corbières (NE Pyrenees, France). Jour. Struc. Geol., XIV, 4, 461-474.

Bordas-LeFloch N., 1999. Diagenèse, compaction et déformation des réservoirs gréseux dans les chaînes plissées, PhD Thesis, Univ. Paris VI, 196p (unpubl.).

Casero P., Roure F. and Vially R, 1991. Tectonic framework and petroleum potential of the Southern Apennines. In : Spencer A.M. (ed.), Generation, accumulation and production of Europe's hydrocarbons, EAPG Spec. Publ., 1, Springer Verlag, 1991, 1-23.

Guilhaumou N., Larroque C., Nicot E., Roure F. and Stéphan J.F., 1994. Mineralized veins resulting from fluid flow in décollement zones of the Sicilian prism : evidence from fluid inclusions. Bull. Soc. Géol. France, 165, 425-436.

Larroque C., Guilhaumou N., Stéphan J.F. and Roure F., 1996. Advection of fluids at the front of the Sicilian Neogene subduction complex. Tectonophysics, 254, 41-55.

Parnaud F., Truskowski I., Gou Y., Gallango O., Pascual J.C., Di Croce J., Passalacqua H. and Roure F., 1995. Petroleum geology of the Eastern Venezuela Basin. In : Tankard A.J., Suarez Soruco R. and Welsink H.J. (eds.), Petroleum geology of South American basins, AAPG Mem., 62, 741-756.

Roure F. and Howell D.G., 2000. Petroleum exploration strategies in Mobile belts. Technip, in press.

Roure F. and Sassi W., 1995. Kinematics of feformation and petroleum system appraisal in Neogene foreland fold-and-thrust belts. Petroleum Geosciences, 1, 253-269.

Sassi W. and Faure J.L., 1997. Role of faults and layer interfaces on the spatial variation of stress regimes in basins : inferences from numerical modelling. Tectonophysics, 266, 101-119.

Van Geet M., Swennen R., Drumishi C. and Roure F., 1999. Diagenesis of Cretaceous to Eocene carbonate reservoirs in the Ionian zone of Albania. In : Beckett D. and Wright V.P. (eds.), Exploration and production of carbonate plays on the southern margin of the Mediterranean Tethys, Geol. Soc. Sp. Vol., in press.

Zoetemeijer R., Sassi W., Roure F. and Cloetingh S., 1992. Geology, 20, 1035-1039. 